\title{
Electrochemical Preparation of Ultrafine Zinc Powder
}

\author{
Ali H. Abbar ${ }^{*}$ Salih A. Rushdi, Husham M. Al-Tameemi \\ Chemical Engineering Department, University of Al-Qadisiyah, Iraq \\ *E-mail: aliabbar68@yahoo.com, Ali.Abbar@qu.edu.iq
}

doi: $10.20964 / 2017.08 .35$

Received: 29 April 2017 / Accepted: 2 June 2017 / Published: 12 July 2017

In this research work, statistical analysis and optimization of the electrolytic preparation of zinc powder from an alkaline solution containing zinc oxide were carried out using Taguchi methodology. The analysis considered the effect of $\mathrm{ZnO}$ concentration (20-80 $\left.\mathrm{g} \mathrm{L}^{-1}\right)$, electrolyte temperature (30-70 $\left.{ }^{\circ} \mathrm{C}\right)$, and current density $\left(150-450 \mathrm{mAcm}^{-2}\right)$ on the specific surface area of zinc powder. The effect of organic additives such as D-sorbitol and sucrose on the morphological structure of zinc powder was studied based on the optimum operating conditions of Taguchi design. XRD-diffraction, atomic force microscopy (AFM), BET, and SEM were used to characterize the zinc powder. The results indicate that $\mathrm{ZnO}$ concentration has the major effect on the specific surface area of zinc powder followed by current density while the temperature has no significant effect on the specific surface area. The optimum conditions for preparing zinc powder at a higher specific surface area and a nanostructure were a current density of $450 \mathrm{mAcm}^{-2}$, an electrolyte temperature of $30{ }^{\circ} \mathrm{C}, \mathrm{ZnO}$ at a concentration of $20 \mathrm{~g} \mathrm{~L}^{-1}$, and D-sorbitol at a concentration of $4 \mathrm{~g} \mathrm{~L}^{-1}$. The current efficiency and energy consumption were $91.3 \%$, and $3.0 \mathrm{KWh} \mathrm{kg}^{-1}$ respectively. The produced powder has a specific surface area of 6.218 $\mathrm{m}^{2} \mathrm{~g}^{-1}$ and an average particle size of $67 \mathrm{~nm}$.

Keywords: Taguchi method, zinc powder, specific surface area, electrodeposition, D-sorbitol, sucrose.

\section{FULL TEXT}

(C) 2017 The Authors. Published by ESG (www.electrochemsci.org). This article is an open access article distributed under the terms and conditions of the Creative Commons Attribution license (http://creativecommons.org/licenses/by/4.0/). 